\title{
Genome-wide transcription analyses in Mycobacterium tuberculosis treated with lupulone
}

\author{
Jian Wei ${ }^{1,4, \#}$, Junchao Liang ${ }^{2, \#}$, Qiyun $\mathrm{Shi}^{2}$, Peng Yuan ${ }^{2}$, Rizeng Meng ${ }^{5}$, \\ Xudong Tang ${ }^{3}, \mathrm{Lu} \mathrm{Yu}^{2}, \mathrm{Na} \mathrm{Guo}^{2}$ \\ ${ }^{1}$ Life Science Department, ChangChun Normal University, Changchun, P.R. China. \\ ${ }^{2}$ Department of Food Quality and Safety, Key Laboratory of Zoonosis Research, Institute of Zoonosis, \\ Ministry of Education, Changchun, P. R. China. \\ ${ }^{3}$ Key Lab for New Drug Research of TCM, Research Institute of Tsinghua University in Shenzhen, \\ Shenzhen, P.R. China. \\ ${ }^{4}$ Bio-Reactor Center, Jilin Agrichultural University, Changchun, P.R. China. \\ ${ }^{5}$ Jilin Enrty-Exit Inspection and Quarantine Bureau, Changchun, P.R.China.
}

Submitted: August 1, 2012; Approved: April 1, 2013.

\begin{abstract}
Mycobacterium tuberculosis (M. tuberculosis), the causative agent of tuberculosis, still causes higher mortality than any other bacterial pathogen until now. With the emergence and spread of multidrugresistant (MDR) and extensively drug-resistant (XDR-TB) strains, it becomes more important to search for alternative targets to develop new antimycobacterial drugs. Lupulone is a compound extracted from Hops (Hurnulus lupulus), which exhibits a good antimicrobial activity against M. tuberculosis with minimal inhibitory concentration (MIC) value of $10 \mu \mathrm{g} / \mathrm{mL}$, but the response mechanisms of lupulone against $M$. tuberculosis are still poorly understood. In this study, we used a commercial oligonucleotide microarray to determine the overall transcriptional response of $M$. tuberculosis $\mathrm{H} 37 \mathrm{Rv}$ triggered by exposure to MIC of lupulone. A total of 540 genes were found to be differentially regulated by lupulone. Of these, 254 genes were upregulated, and 286 genes were downregulated. A number of important genes were significantly regulated which are involved in various pathways, such as surface-exposed lipids, cytochrome P450 enzymes, PE/PPE multigene families, $\mathrm{ABC}$ transporters, and protein synthesis. Real-time quantitative RT-PCR was performed for choosed genes to verified the microarray results. To our knowledge, this genome-wide transcriptomics approach has produced the first insights into the response of $M$. tuberculosis to a lupulone challenge.
\end{abstract}

Key words: antimycobacterial avticity, lupulone, DNA microarray.

\section{Introduction}

Among infectious diseases, tuberculosis (TB) caused by Mycobacterium tuberculosis ( $M$. tuberculosis) is the major leading reason of death in the world, killing nearly $3,000,000$ people annually (Ates et al., 2008). Accompany with the human immunodeficiency virus (HIV), together with the emergence of multidrug resistant tuberculosis (MDR-TB) and extensively drug resistant tuberculosis
(XDR-TB) strains, has represented mycobacteria as a primary public health threat. Thus, the new drugs against TB owning new target are urgently needed (Youm and Saier, 2012).

Plants and other natural materials may prove to be valuable sources of useful new antimycobacterial drugs (Cantrell et al., 2001). Lupulon (structure shown in Figure 1), a compound extracted from Hops (Hurnulus lupulus), was described as the antibiotic constituents (Lewis et al.,

Send correspondence to N. Guo. Department of Food Quality and Safety, College of Quartermaster Technology, Jilin University, Xi'an Road 5333\#, Changchun 130062, P. R. China. E-mail: abas1980@163.com.

"These authors contributed equally to this work. 
1949). It was identified to be bacteriostatic against multiple human (Chin et al., 1949; Sacks and Humphreys, 1951) and veterinary bacterial pathogens (Siragusa et al., 2008). The use of lupulone for TB treatment was documented in the scientific literature as early as in 1951 (Erdmann and Phytoncides, 1951). Interestingly, previous reports showed that lupulone inhibit nitric oxide production in RAW cells (Zhao et al., 2003) and have potent radical scavenging activity and lipid peroxidation inhibitory activity (Tagashira et al., 1995). It was suggested that lupulone acts by causing membrane leakage (Teuber and Schmalreck, 1973). However, the further research on action mechanism of lupulone is very poor, this prohibit the further availability of lupulone to be the mainstream antibiotics that treat TB.

In the past several years, DNA microarray technology has been used to discover gene functions, to understand biochemical pathways and to discver drug targets ( $\mathrm{Yu}$ et al., 2007, 2008, 2010; Liang et al., 2011). This study is designed to analyze the genome-wide transcriptional changes in response to lupulone against $M$. tuberculosis with commercial agilent microarrays, and a subset of the microarray results were verified by real-time RT-PCR.

\section{Materials and Methods}

\section{Bacterial strain and materials}

The M. tuberculosis strain H37Rv (American Type Culture Collection 27294) was obtained from the National Institute for the Control of Pharmaceutical and Biological Products. Middlebrook 7H9 broth and OADC (oleic acid, albumin, dextrose and catalase) was purchased from BD Biosciences, Inc., Sparks, MD. Alamar Blue was obtained from Trek Diagnostic Systems (Westlake, OH, US). TRIzol was purchased from Invitrogen. Tween 80 was purchased from Sigma-Aldrich. Lupulone was obtained from Sigma-Aldrich. Stock solutions of lupulone were prepared in dimethyl sulfoxide (DMSO, Sigma-Aldrich).

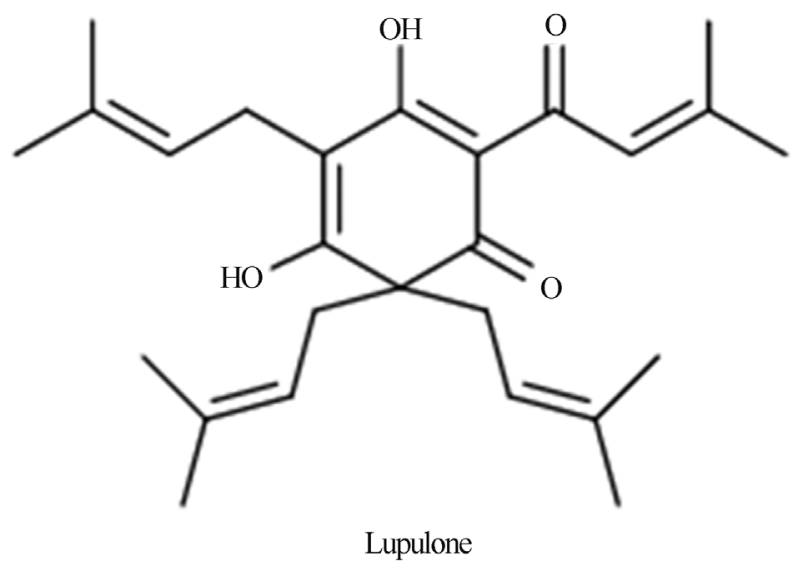

Figure 1 - Chemical formula of lupulone.
The minimal inhibitory concentration (MIC) determinations

The activity of lupulone against the aforementioned M. tuberculosis strain was tested using a microplate Alamar Blue assay (MABA) according to the method of Franzblau et al. (1998), as modified by Jiménez-Arellanes et al. (2003). Briefly, sterile distilled water $(200 \mu \mathrm{L})$ was poured into the outer perimeter wells of the microplate. All other wells received $100 \mu \mathrm{L}$ of supplemented Middlebrook 7H9 broth. Then, working extract solutions $(100 \mu \mathrm{L})$ were poured into the first well of each row and two-fold dilution series were made from these solutions through the microplate column. The test inoculum $(100 \mu \mathrm{L})$ was added to all testing wells, as well as to the drug-free control wells. The final concentration of DMSO in the wells was approximately $1 \% \mathrm{v} / \mathrm{v}$. At the same time, controls diluted 10:100 and 1:100 were prepared from the bacterial suspension, representing the growth of $10 \%$ and $1 \%$ of the bacterial population tested, respectively. The final concentrations of lupulone tested ranged from 160 to $0.3125 \mu \mathrm{g} / \mathrm{mL}$. Each concentration was assayed in duplicate. Each microplate was incubated for five days at $37{ }^{\circ} \mathrm{C}$ in a $5 \% \mathrm{CO}_{2}$ atmosphere in a sealed plastic bag. Following incubation, a control growth was developed with a mixture of $20 \mu \mathrm{L}$ of Alamar Blue solution (Trek Diagnostics, Westlake, $\mathrm{OH}$ ) and $12 \mu \mathrm{L}$ of sterile $10 \%$ Tween 80 . The plates were re-incubated at $37^{\circ} \mathrm{C}$ for $24 \mathrm{~h}$. After this incubation, if the well turned pink, all of the wells received a mixture of Alamar Blue and Tween solutions in the same way as described above and were incubated for an additional $24 \mathrm{~h}$. Wells with a well-defined pink color were scored as positive for growth. The MIC was defined as the lowest concentration of a sample that prevents a color change to pink. Extracts were considered active if they showed an $\mathrm{MIC} \leq 200 \mu \mathrm{g} / \mathrm{mL}$.

\section{Cell culture and drug exposure for microarray experiments}

A frozen stock of M. tuberculosis strain H37Rv was inoculated into $5 \mathrm{~mL}$ of the Middlebrook $7 \mathrm{H} 9$ broth containing $0.05 \%$ Tween $80,0.2 \%$ glycerol and $10 \%$ oleic acid, albumin, dextrose and catalase (OADC) at $37{ }^{\circ} \mathrm{C}$ for five days. Then, the culture was transferred into $200 \mathrm{~mL}$ of $7 \mathrm{H} 9$ media and incubated at $37^{\circ} \mathrm{C}$ with shaking at $150 \mathrm{rpm}$ until the $\mathrm{OD}_{600}$ reached 0.7 . Subsequently, $200 \mathrm{~mL}$ of $7 \mathrm{H} 9$ broth was divided into two flasks, each of which contained $100 \mathrm{~mL}$ of culture; the cells were harvested by centrifugation for RNA preparation. A lupulone stock solution was prepared in dimethyl sulfoxide (DMSO). Drug treatment was conducted by adding the stock solution to one of the cultures to achieve a final concentration of $10 \mu \mathrm{g} / \mathrm{mL}$ (MIC). Untreated paired control bacteria were grown under identical conditions to treated bacteria, with the exception that no drug was added. The final concentration of DMSO 
in each culture could not exceed $0.05 \%(\mathrm{v} / \mathrm{v})$ (Slayden et al., 2006). Two independent $200 \mathrm{~mL}$ cultures were prepared to act as biological repeats. Upon completion of the predefined duration $(4 \mathrm{~h})$ of drug and control treatments, the bacteria were harvested by centrifugation and then stored for RNA extraction.

\section{RNA isolation and cDNA labeling}

Bacterial cultures were centrifuged for $5 \mathrm{~min}$ at $2500 \mathrm{~g}$. After removing the supernatant, the pellets were frozen on dry ice and stored at $-80^{\circ} \mathrm{C}$. Total RNA was harvested using TRIzol (Invitrogen) and an RNeasy kit (Qiagen) according to the manufacturer's instructions, including a DNase digestion step. The RNA samples were redissolved to produce a final concentration of 300$500 \mathrm{ng} / \mu \mathrm{L}$. For every RNA sample, $120 \mu \mathrm{L}$ was sent to Shanghai Bio Co., Ltd. and further examined through a quality and quantity test based on electrophoresis before microarray hybridization.

Fluorescently labeled cRNA, transcribed from cDNA, was produced using a Quick Amp Kit, PLUS, Two-Color (Agilent p/n 5190-0444) in Agilent's SureHyb Hybridization Chambers. The cRNA was labeled with the fluorescent dyes Cy5 and Cy3-CTP. Double-stranded cDNA was synthesized from $1 \mu \mathrm{g}$ of total RNA using a cDNA synthesis kit according to the manufacturer's protocol (Quick Amp Kit, Agilent). T7 promoter primers were used instead of the poly-T primer provided in the kit. The Cy3- and Cy5-labeled products were purified using an RNeasy Mini Kit (Qiagen). An aliquot of $1 \mu \mathrm{L}$ of purified cRNA was used to determine the yield and specific activity with a NanoDrop ND-1000. The amount of Cy3- or Cy5labeled cRNA was determined by measuring the absorbance at A260 nm, A280 nm, A550 nm (Cy3) and A650 (Cy5). The specific activity (pmol dye per $\mu \mathrm{g}$ cRNA) of the cRNA can be obtained from the following calculation: specific activity $=($ concentration of $\mathrm{Cy} 3 / \mathrm{Cy} 5) /[$ (concentration of cRNA) $* 1000]=$ pmol Cy3/Cy5 per $\mu \mathrm{g}$ cRNA. If the yield is $<825 \mathrm{ng}$ and the specific activity is $<8.0 \mathrm{pmol}$ Cy3/Cy5 per $\mu \mathrm{g}$ of cRNA, the experiment does not proceed to the hybridization step. cRNA was repeatedly prepared.

\section{Microarray hybridization and data analysis}

M. tuberculosis microarray slides consisted of 4690 60-mer oligonucleotides representing 4004 open reading frames from $M$. tuberculosis strain $\mathrm{H} 37 \mathrm{Rv}$ and 686 unique open reading frames from strain CDC1551 that are not present in the H37Rv strain's annotated gene complement. Microarray hybridization was performed in Agilent's SureHyb Hybridization Chambers using the Agilent Gene Expression Hybridization Kit. After hybridization and washing, the processed slides were scanned using an Agilent DNA microarray scanner (part number G2505B) with the settings recommended by Agilent Technologies.
The resulting text files, which were extracted using Agilent Feature Extraction Software (version 10.5.1.1), were imported into Agilent GeneSpring GX software (version 11.0) for further analysis. The microarray datasets were normalized in Agilent Feature Extraction Software (mainly LOWESS normalization) and then genes marked as present were chosen for further analysis. Differentially expressed genes were identified through Volcano Plot screening. Cluster analysis was carried out by hierarchical clustering (HCL). In addition to the significance analysis of the microarrays, a fold change analysis was performed in which the ratios of the geometric means of the expression intensities of the corresponding genes in the lupulone treatment samples relative to control samples were calculated. The ratios were reported as the fold change up or down. To select differentially expressed genes, the genes were considered to be significantly differentially hybridized compared with the M. tuberculosis control if they displayed at least a twofold difference in the ratio (Frota et al., 2004).

\section{Quantitative real-time RT-PCR assays}

Aliquots of the RNA preparations from the lupulonetreated and control samples used in the microarray experiments were saved for follow-up quantitative real-time RTPCR. Quantitative real-time RT-PCRs were performed in triplicate using the 7000 Sequence Detection System (Applied Biosystems, Foster City, CA) according to a previously described procedure (Yu et al., 2007). The primer sequences used are listed in Table 1.

\section{Results}

\section{Gene expression changes of $M$. tuberculosis in response to lupulone treatment}

In the study, the MIC value of lupulone against $M$. tuberculosis H37Rv (ATCC 27294) was $10 \mu \mathrm{g} / \mathrm{mL}$. We analysed the microarray data and found that there were 540 genes significantly differentially expressed after $4 \mathrm{~h}$ of exposure to MIC concentration $(10 \mu \mathrm{g} / \mathrm{mL})$ of lupulone compared to untreated M. tuberculosis H37Rv (ATCC 27294) cells. Previous study shows that RNA preparation following $4 \mathrm{~h}$ of drug treatment may deliver the most meaningful results (Provvedi et al., 2009). This is the reason why incubation for $4 \mathrm{~h}$ was chosen in our study.

Among these, 254 genes were significantly increased in expression and 286 genes were significantly inhibited. Most of these genes were classed as having an unclassified role category not yet assigned (20.6\%), and the others were classified as involved in cell envelope (3.0\%), cellular processes $(2.6 \%)$, central intermediary metabolism $(1.9 \%)$, conserved hypothetical protein $(15.4 \%)$, DNA metabolism (2.2\%), energy metabolism (6.1\%), mobile and extrachromosomal element functions $(2.6 \%)$, protein fate $(2.0 \%)$, protein synthesis $(2.8 \%)$, regulatory functions $(3.9 \%)$, transport and binding proteins $(3.9 \%)$, hypothetical protein 
Table 1 - Primers used in real-time RT-PCR with SYBR green probes.

\begin{tabular}{lcl}
\hline Primer & Systematic name & Sequence $\left(5^{\prime}\right.$ - ${ }^{\prime}$ ') \\
\hline 16S rRNAfor & & GCACCGGCCAACTACGTG \\
16S rRNArev & & GAACAACGCGACAAACCACC \\
Rv1686c for & Rv1686c & TCGGGCTCGGTCTATTGTGTA \\
Rv1686 rev & Rv1686c & GGATGAACTGTACGGCCTGAA \\
Rv2626c for & Rv2626c & GCTCAACGTCATGGAAGAACA \\
Rv2626c rev & Rv2626c & CCAAGCGGTGCTCTGAGATGA \\
$n r d Z$ for & Rv0570 & GGCTGGGAGTCATGGGTTT \\
$n r d Z$ rev & Rv0570 & GCTTCTTCACTGTCGTACGGAAT \\
$f r d B$ for & Rv1553 & TGGAGCCGATGCGAAACTT \\
$f r d B$ rev & Rv1553 & GAAGTCACTGATGTCGACAACGA \\
$h s p X$ for & Rv2031c & GACAAGGACGTCGACATTATGG \\
$h s p X$ rev & Rv2031c & CGCTCGGCCTTGATGGTCAGCTGA \\
$m m p S 5$ for & Rv0677c & CAAGGTGGTGGAGTACGAAGTTT \\
$m m p S 5$ rev & Rv0677c & TCGAGGTCCAGGTAGTTGATGTTG \\
$e t h A$ for & Rv3854c & CCCATCCTCGAGTACGTCAAGA \\
$e t h A$ rev & Rv3854c & CGGATATGCCTGTCGATTCCA \\
$r p l N$ for & Rv0714 & GGCACCCGCATTTTTGG \\
$r p l N$ rev & Rv0714 & CCAGCGAAATGATCTTCATAAACC \\
$h t p X$ for & Rv0563 & CATCCTGCGTATCCTCAATGAG \\
$h t p X$ rev & Rv0563 & TCGCGGTTGTAGACGTGAGA \\
$p p s A$ for & Rv2931 & CCAAATCAGCACTTCGAAACC \\
$i c l$ for & Rv2931 & CCATTCAGTTTGTGTGTCAACGA \\
$i c l$ rev & Rv0467 & AACCAGATGAGCGCGTATGTC \\
& & \\
& & \\
& &
\end{tabular}

(20.0\%), unknown function (7.8\%) and the other categories $(5.4 \%)$. The microarray-related data were submitted to Gene Expression Omnibus (GEO) under accession number GSE31732. A complete list of all of the genes differentially expressed due to lupulone treatment can be found in the Supplementary material (Table S1). Figure 2 provides a summary of the differentially regulated genes grouped by functional categories. Herein, we focused the interest mainly on specific genes that may affect the organism's survival in the presence of lupulone. These genes will be discussed in the Discussion section.

\section{Validation of microarray data by real-time RT-PCR}

Using the same RNA samples used for the original microarray experiment against eleven selected genes (Rv1686c, Rv2626c, $n r d Z, f r d B, h s p X, m m p S 5$, ethA, rplN, $h t p X, p p s A$ and $i c l$ ), real-time quantitative RT-PCR was conducted to validate the microarray data. Overall, there was great accordance between the microarray data and the real-time RT-PCR data for all 11 genes (Table 2). When exposed to lupulone, there were 6 genes induced and 5 genes reduced. However, the numerical values of some genes (Rv1686c and mmpS5) determined by RT-PCR were much higher than those obtained from the microarray. In situa- tions in which poor or no hybridization signals were generated for one of the samples tested, the n-fold induction values can be under- or overestimated as a result of the higher efficiency of the RT step (no cyanine dye incorporation) and/or the higher sensitivity of the real-time PCR (Liu et al., 2005). The expression levels of other genes (Rv2626c, $i c l, p p s A, n r d Z, f r d B, h s p X$, ethA, rplN and $h t p X)$ did not differ markedly between the microarray data and real-time RT-PCR data. In summary, the real-time RT-PCR results provided independent verification of our DNA microarray results.

\section{Discussion}

Induction of the genes involved in cytochrome P450 enzymes

The human pathogen $M$. tuberculosis encodes 20 cytochrome P450 (P450) enzymes. Gene essentiality for viability or host infection was demonstrated for many P450s, such as CYP128, CYP121 and CYP125 (McLean et al., 2010). In the study, we found the genes cyp140, cyp138, cyp 128 and cyp124 invovled in cytochrome P450 enzymes (CYP450s) were upregulated more than 2-fold following exposure to lupulone. CYP450s are heme-containing 
Table 2 - Real-time RT-PCR analysis of gene expression.

\begin{tabular}{|c|c|c|c|c|}
\hline Systematic name & Gene & Description & $\begin{array}{c}\text { Fold change } \\
\text { RT-PCR }\end{array}$ & $\begin{array}{c}\text { Systematic name } \\
\text { Microarray }\end{array}$ \\
\hline Rv1686c & Rv1686c & integral membrane protein $\mathrm{ABC}$ transporter & $+86.34( \pm 2.8)^{\mathrm{a}}$ & +14.99 \\
\hline Rv2626c & Rv2626c & hypothetical protein & $+2.71( \pm 0.24)$ & +3.12 \\
\hline Rv0570 & $n r d Z$ & ribonucleoside-diphosphate reductase large subunit & $+2.84( \pm 0.35)$ & +2.02 \\
\hline Rv1553 & $f r d B$ & fumarate reductase iron-sulfur subunit & $+3.18( \pm 0.29)$ & +2.37 \\
\hline Rv2031c & $h s p X$ & heat shock protein & $+2.93( \pm 0.29)$ & +2.48 \\
\hline $\mathrm{Rv} 0677 \mathrm{c}$ & $m m p S 5$ & hypothetical protein & $+30.88( \pm 1.92)$ & +12.04 \\
\hline $\operatorname{Rv} 3854 c$ & ethA & monooxygenase & $-5.61( \pm 0.49)$ & -2.44 \\
\hline Rv0714 & $r p l N$ & 50S ribosomal protein L14 & $-2.06( \pm 0.24)$ & -2.34 \\
\hline Rv0563 & $h t p X$ & heat shock protein & $-2.47( \pm 0.21)$ & -2.04 \\
\hline Rv2931 & pps $A$ & phenolpthiocerol synthesis type-I polyketide synthase & $-3.64( \pm 0.27)$ & -2.02 \\
\hline Rv0467 & $i c l$ & isocitrate lyase & $-3.43( \pm 0.31)$ & -2.28 \\
\hline
\end{tabular}

“+” and "-"indicated increase and reduction, respectively; a, indicated "mean \pm standard deviations".

monooxygenases, well known for their roles in metabolism of fatty acids, steroids, and other lipophilic molecules (Denisov et al., 2005). The M. tuberculosis genome sequence revealed an unexpectedly high number of CYP450s (Cole et al., 2001). Among these, the second largest of the $M$. tuberculosis CYP450s is CYP128 (53,313 Da) encoded by cyp 128 that is predicted to metabolize menaquinone as a step towards its sulfation (Holsclaw et al., 2008). The creation of genome-wide transposon libraries enabled the classification of CYP128 as a gene required for optimal growth of $M$. tuberculosis, and as upregulated in cell starvation (McLean et al., 2007). CYP124 encoded by cyp124 is found in pathogenic and nonpathogenic mycobacteria species, actinomycetes, and some proteobacteria, which suggests that it has an important catalytic activity (Ouellet et $a l ., 2010)$. It is located adjacent to a three-gene operon containing a sulfotransferase (Sft3, Rv2267c) that catalyzes the PAPS-dependent sulfation at the $\omega$-position of menaquinone MK-9 DH-2 (Holsclaw et al., 2008; Mougous et al., 2006). The biochemical characterization of CYP124 includes identifying a series of substrates consistent with $\omega$-hydroxylase activity and, importantly, a marked preference for lipids containing methyl branching (Johnston et al., 2009). To date, gene disruption and gene deletion studies have shown that $M$. tuberculosis cyp 128 is an essential gene for cell growth and viability (McLean et al., 2008). Cyp138 are induced at elevated temperatures (Stewart et $a l ., 2002)$. Some studies have reinforced the fact that $M$. $t u$ berculosis $\mathrm{P} 450$ s play important cellular roles and are most important in the pathogen's response to environmental stimuli and immune/chemical abuse (McLean et al., 2007). The upregulation of the M. tuberculosis cytochrome P450 enzyme genes may be a adaptive response to environmental changes to survive. The trigger for the induced transcrip- tion of the P450s in M. tuberculosis following a lupulone challenge requires further study.

\section{PPE and PE genes differentially regulated by Iupulone}

When H37Rv cells were exposed to lupulone, a number of $P E$ and $P P E$ genes were differentially regulated, including PPE29, PPE47, PPE67, PE_PGRS15, PE_PGRS46, PE_PGRS58, PE2, PE13, PE23, PE22 and PE25. The genes PPE29, PPE47, PPE67, PE2, PE13, $P E 22, P E 23, P E 25$ were inhibited following exposure to lupulone, while in contrast, the genes PEPGRS15, PE_PGRS46, PE_PGRS58 were upregulated. Two large protein families, the PE and PPE, named for the conserved proline and glutamate residues near the $\mathrm{N}$-terminal region of the encoded proteins, contain about 100 PE members and more than 60 PPE members in the genome. Although no structure or precise function is known for any member of these families, it has been suggested that some PE_PGRS proteins have been found to associate with the cell wall (Banu et al., 2002; Delogu et al., 2004) and to influence interactions with eukaryotic cells (Brennan et al., 2001), and some members may play a role in immune evasion (Vordermeier et al., 2012). Members of the PE and PPE families also have been linked to virulence (Ramakrishnan et al., 2000), and some PPE proteins have been found to be immunodominant antigens (Choudhary et al., 2003). The $\mathrm{PE} / \mathrm{PPE}$ gene families have been found to play critical roles in host-pathogen interactions. As previous study reported frequent natural homologous recombination events within and between PE/PPE genes (Karboul et al., 2008), such a propensity for recombination could represent an ideal adaptive mechanism that ensures the creation of new recombined variant molecules in response to new selective immune pressures. Moreover, it is concluded that due to in- 
dividual PE and PPE proteins failing to be expressed in a soluble form, individual $\mathrm{PE}$ proteins are likely protein partners for PPE proteins (Strong et al., 2006). In this study, since many $P E$ and $P P E$ genes were differentially regulated when exposed to lupulone, the survival ability of tuberculosis may be reduced by destroying the ratio of PE and PPE.

\section{Downregulation of genes encoding 50 s ribosomal proteins exposed to lupulone}

The ribosome is the factory where protein synthesis occurs. The structure of the ribosome in bacteria and human cells differs significantly and this difference allows some antibiotics to specifically kill bacteria. Previouse study showed that the divergent properties of the mycobacterial ribosomes may be related to some exceptional properties of mycobacteria, e.g. their slow growth (Shasmal and Sengupta, 2012). In the presence of lupulone, seven genes ( $r p l Y, r p l X, r p l N, r p l J$ and $r p l E$ ) encoding 50S ribosome protein were downregulated by 2.06 to 2.35 -fold (showed in Table S1). The genes $r p l Y, r p l X, r p l N, r p l J, r p l E$ encoded 50 S ribosomal protein L25, L24, L14, L10, L5, respectively, which belong to the rpl family. The aforementioned genes participate in 50s ribosomal protein synthesis and modification. Moreover, the gene frr encoding ribosome recycling factor was upregulated by 2.02 -fold. The gene infC which are essential for the initiation of translation was also upregulated by 2.20 -fold. Hence, our results suggested that the downregulation of the genes may result in reduced amounts of functional ribosomes and repressed translational capacity. The ribosome is a multiprotein complex and the protein-protein interactions of the ribosomal subunits could be attractive targets for new drug.

\section{Inhibition of genes ivovled in surface-exposed lipids when exposed to lupulone}

Some research has demonstrated that proteins encoded by genes at the M. tuberculosis fadD26-mmpL7 locus (fadD26, ppsA to ppsE, drrA to $\operatorname{drr} C$, papA5, mas, fadD28, and $m m p L 7$ ) play major roles in phthiodiolone dimycocerosate (PDIM) biosynthesis and secretion (Camacho et al., 1999; Rousseau et al., 2004). Phthiocerol and phenolphthiocerol esterified with multiple methylbranched long chain fatty acids belonged to surfaceexposed lipids that been found to be unique to pathogenic mycobacteria. Diesters of phthiocerol and phenolphthiocerol are important virulence factors of M. tuberculosis. Moreover, the phthiocerol and phthiodiolone dimycocerosate esters (PDIMs) comprise a category of virulenceenhancing lipids that act as defensive, offensive, or adaptive effectors of virulence.

In our srudy, the genes fadD26, pps $A, p p s B, p p s C$, ppsD, ppsE, $\operatorname{drr} B, \operatorname{drr} C$, and $p a p A 5$ were downregulated more than 2-fold when M. tuberculosis strains were exposed to lupulone. Type I modular polyketide synthase (PKS) encoded by the genes pps $A-E$ was responsible for the synthesis of phthiocerol and phenolphthiocerol through the elongation of a C20-C22 fatty acyl chain or an acyl chain which contained a phenol moiety with three malonyl-CoA and two methylmalonyl-CoA units. FadD26 encoded by the gene fadD26 belongs to a family of long-chain fatty acyl-AMP ligases activating longchain fatty acids as acyladenylates for subsequent transfer to their cognate multifunctional polyketide synthases (Trivedi et al., 2004). The ABC-type transporter DrrB and DrrC encoded by the genes $d r r B$ and $\operatorname{drr} C$ are both the daunorubicin-DIM-transport integral membrane protein. DrrB behaves as a functional doxorubicin efflux pump and drrC are necessary for the proper localization of dimycocerosyl phthiocerol (DIM) in the cell envelope (Choudhuri et al., 2002; Camacho et al., 2001). Additionally, Onwueme et al. (2004) have recently proposed that PapA5 is required for diesterification of phthiocerol with mycocerosate to produce PDIM. In the other study, $M$. tuberculosis ppsA-E-deficient mutants fail to synthesize DIM and are more sensitive to sodium dodecyl sulfate (SDS), which appear an increase in their outer membrane permeability (Nikaido and Vaara, 1985). The inactivation of fadD26 in M. tuberculosis strains has been unable to synthesize PDIM and are attenuated in a mouse model of TB infection (Camacho et al., 1999, 2001). In conclusion, downregulation of the genes may affect outer membrane or cell wall permeability of M. tuberculosis, this fingding may be consistnet with early reports that lupulone acts by causing membrane leakage (Teuber and Schmalreck, 1973).

\section{Significant regulation of the genes involved in $A B C$ transporters}

The ABC transporters genes irtA, irtB, cysA1, cys $T$ and $c y s W$ were significantly downregulated following exposure to lupulone. The genes irtA and irtB encoding ATP-binding cassette transponer ( $\mathrm{ABC}$ transporter) IrtA and IrtB (Braibant et al., 2000) highly similar to the YbtPQ system of Yersinia pestis (Fetherson et al., 1999). The genes irt $A$ and $i r t B$ are part of the iron acquisition machinery of $M$. tuberculosis and do not participate in siderophore synthesis or secretion but are required for efficient utilization of iron from $\mathrm{Fe}$-carboxymycobactin (Rodriguez and Smith, 2006). Previous study has demonstrates that inactivation of $M$. tuberculosis irtA (Rv1348) or irtB (Rv1349) genes results in decreased ability of $M$. tuberculosis to replicate in low-iron medium and to utilize $\mathrm{Fe} 3$-ExMb as the sole iron source (Ryndak et al., 2010). Moreover, it is reported IrtAB is necessary for normal multiplication of M. tuberculosis in human Macrophages (Rodriguez and Smith, 2006). The genes cysT and cys $W$ encoded sulfate-transport integral membrane proteins while the gene cysAl encoded sulfate-transport ATP-binding protein. These proteins are all ABC transporters and play important roles in sulfate acquisition. The CysTWA SubI ABC transporetr complex is responsible 
for the active transport of inorganic sulfate across the mycobacterial cell membrane (Mehra and Kaushal, 2009). Sulfate assimilation is crucial for M. tuberculosis. It is an essential bionutrient with a key role in biosynthesis of cysteine, mycothiol and coenzyme A (Mehra and Kaushal, 2009). So our results suggest that the downregulation of the genes may affect the ability of $M$. tuberculosis to efficiently acquire iron, normal multiply, sulfate acquisition and further influence survival when exposed to lupulone.

In contrast, the $\mathrm{ABC}$ transporters genes Rv1686c, Rv1687c, Rv1218c, Rv1217c and Rv1739c were induced 14.99-fold, 5.08-fold, 4.30-fold, 2.74-fold and 2.25-fold respectively. It has been reported that most of the compound classes had significantly better bactericidal activity in the $\Delta R v 1218 \mathrm{c}$ mutant than in the wild-type H37Rv, which suggested $R v 1218 c$ gene product was related to effluxing these compounds from M. tuberculosis (Balganesh et al., 2010). The genes Rv1686c and Rv1687c were also highly induced when M. tuberculosis in response to the 5 MIC triclosan treatments (Betts et al., 2003). Moreover, when M. tuberculosis was under hypoxic conditions, the gene Rv1739c was also found to be upregulated (Tyagi and Saini, 2004). Hence, the induction of the genes may be adaptive response to lupulone.

\section{Conclusion}

In summary, our results showed that lupulone has potential antimycobacterial activity and our DNA microarray analysis demonstrated that lupulone affected a number of important genes involved in different pathways in M. tuberculosis. These findings may have important implications for understanding the responsive mechanisms of M. tuberculosis to lupulone treatment.

\section{Acknowledgments}

We specially thank for the ideas and helps from Professor Yossef Av-Gay (Department of Medicine, Division of Infectious Diseases, University of British Columbia). Financial supports for this work came from the Fund for National Nature Science Foundation of China (No. 31000822, 31271951 and 31172364), the Specialized Research Fund for Important National Science \& Technology Specific Projects (2012ZX10003002), the Program for New Century Excellent Talents in University ( NCET-09-0434 and NCET-13-0245), China Postdoctoral Science Foundation (2013M530142) and Shenzhen biological special funds for industrial development aid key basic research project (JC201005280643A).

\section{References}

Ates O, Musellim B, Ongen G, Topal-Sarikaya A (2008) Interleukin-10 and tumor necrosis factor-alpha gene polymorphisms in tuberculosis. J Clin Immunol. 28:232-236.
Balganesh M, Kuruppath S, Marcel N, Sharma S, Nair A, Sharma U (2010) Rv1218c, an ABC Transporter of Mycobacterium tuberculosis with Implications in Drug Discovery. Antimicrob Agents Chemother 54:5167-5172.

Banu S, Honoré N, Saint-Joanis B, Philpott D, Prévost MC, Cole ST (2002) Are the PE-PGRS proteins of Mycobacterium tuberculosis variable surface antigens? Mol Microbiol 44:919.

Betts JC, McLaren A, Lennon MG, Kelly FM, Lukey PT, Blakemore SJ, Duncan K (2003) Signature gene expression profiles discriminate between isoniazid-, thiolactomycin-, and triclosan-treated Mycobacterium tuberculosis. Antimicrob Agents Chemother 47:2903-2913.

Braibant M, Gilot P, Content J (2000) The ATP binding cassette (ABC) transport systems of Mycobacterium tuberculosis. FEBS. Microbiol Rev 24:449-467.

Brennan MJ, Delogu G, Chen Y, Bardarov S, Kriakov J, Alavi M, Jacobs WR (2001) Jr. Evidence that mycobacterial PE_PGRS proteins are cell surface constituents that influence interactions with other cells. Infect Immun 69:73267333.

Camacho LR, Constant P, Raynaud C, Laneelle MA, Triccas JA, Gicquel B, Daffe M, Guilhot C (2001) Analysis of the phthiocerol dimycocerosate locus of Mycobacterium tuberculosis. Evidence that this lipid is involved in the cell wall permeability barrier. J Biol Chem 276:19845-19854.

Camacho LR, Ensergueix D, Perez E, Gicquel B, Guilhot C (1999) Identification of a virulence gene cluster of Mycobacterium tuberculosis by signature-tagged transposon mutagenesis. Mol Microbiol 34:257-267.

Cantrell CL, Franzblau SG, Fischer NH (2001) Antimycobacterial plant terpenoids. Planta Med 67:685-694.

Chin YC, Chang NC, Anderson HH (1949) Factors influencing the antibiotic activity of lupulon. J Clin Invest 28:909-915.

Choudhary RK, Mukhopadhyay S, Chakhaiyar P, Sharma N, Murthy KJ, Katoch VM, Hasnain SE (2003) PPE antigen Rv2430c of Mycobacterium tuberculosis induces a strong B-cell response. Infect Immun. 71:6338-6343.

Choudhuri BS, Bhakta S, Barik R, Basu J, Kundu M, Chakrabarti $P$ (2002) Overexpression and functional characterization of an ABC (ATP-binding cassette) transporter encoded by the genes drrA and drrB of Mycobacterium tuberculosis. Biochem J 367:279-285.

Cole ST, Eiglmeierf K, Parkhill J, James KD, Thomson NR, Wheeler PR, Honoré N, Garnier T, Churcher C, Harris D, Mungall K, Basham D, Brown D, Chillingworth T, Connor R, Davies RM, Devlin K, Duthoy S, Feltwell T, Fraser A, Hamlin N, Holroyd S, Hornsby T, Jagels K, Lacroix C, Maclean J, Moule S, Murphy L, Oliver K, Quail MA, Rajandream MA, Rutherford KM, Rutter S, Seeger K, Simon S, Simmonds M, Skelton J, Squares R, Squares S, Stevens K, Taylor K, Whitehead S, Woodward JR, Barrell BG (2001) Massive gene decay in the leprosy bacillus. Nature 409:1007-1011.

Delogu G, Pusceddu C, Bua A, Fadda G, Brennan MJ, Zanetti S (2004) Rv1818c-encoded PE_PGRS protein of Mycobacterium tuberculosis is surface exposed and influences bacterial cell structure. Mol Microbiol 52:725-733.

Denisov IG, Makris TM, Sligar SG, Schlichting I (2005) Structure and chemistry of cytochrome P450. Chem. Rev 105:22532277. 
Erdmann WF, Phytoncides I (1951) Lupulone and humulone; their antibacterial action and their use in tuberculous infections. Pharmazie 6:442-451.

Fetherson JD, Bertolino VJ, Perry RD (1999) YbtP and YbtQ two $\mathrm{ABC}$ transporters required for iron uptake in Yersinia pestis. Mol Microbiol 32:289-299.

Franzblau SG, Witzig RS, McLaughlin JC, Torres P, Madico G, Hernandez A, Degnan MT, Cook MB, Quenzer VK, Ferguson RM, Gilman RH (1998) Rapid low-technology MIC determination with clinical, Mycobacterium tuberculosis isolates by using the microplate Alamar Blue assay. J Clin Microbiol 36:362-366.

Frota CC, Hunt DM, Buxton RS, Rickman L, Hinds J, Kremer K, van Soolingen D, Colston MJ (2004) Genome structure in the vole bacillus, Mycobacterium microti, a member of the Mycobacterium tuberculosis complex with a low virulence for humans. Microbiology 150:1519-1527.

Holsclaw CM, Sogi KM, Gilmore SA, Schelle MW, Leavell MD, Bertozzi CR, Leary JA (2008) Structural characterization of a novel sulfated menaquinone produced by stf3 from $\mathrm{Myco}$ bacterium tuberculosis. ACS Chem Biol 3:619-624.

Jiménez-Arellanes A, Meckes M, Ramírez R, Torres J, LunaHerrera J (2003) Activity against multidrug-resistantn Mycobacterium tuberculosis in mexican plants used to treat respiratory diseases. Phytother Res 17:903-908.

Johnston JB, Kells PM, Podust LM, Ortiz de Montellano PR (2009) Biochemical and structural characterization of CYP124: A methyl-branched lipid $\omega$-hydroxylase from $M y$ cobacterium tuberculosis. Proc Natl Acad Sci USA. 106:20687-20692.

Karboul A, Mazza A, Gey van Pittius NC, Ho JL, Brousseau R, Mardassi H (2008) Frequent homologous recombination events in Mycobacterium tuberculosis PE/PPE multigene families:potential role in antigenic variability. $\mathrm{J}$ Bacteriol 190:7838-7846.

Lewis JC, Alderton G, Carson JF, Reynolds DM, Maclay WD (1949) Lupulon and humulon, antibiotic constituents of hops. J Clin Invest 28:916-919.

Liang J, Zeng F, Guo A, Liu L, Guo N, Li L, Jin J, Wu X, Liu M, Zhao D, Li Y, Jin Q, Yu L (2011) Microarray analysis of the chelerythrine-induced transcriptome of Mycobacterium tuberculosis. Curr Microbiol. 62:1200-1208.

Liu TT, Lee RE, Barker KS, Lee RE, Wei L, Homayouni R, Rogers PD (2005) Genome-wide expression profiling of the response to azole, polyene, echinocandin, and pyrimidine antifungal agents in Candida albicans. Antimicrob Agents Chemother 49:2226-2236.

McLean KJ, Belcher J, Driscoll MD, Fernandez CC, Le Van D, Bui S, Golovanova M, Munro AW (2010) The Mycobacterium tuberculosis cytochromes P450: physiology, biochemistry \& molecular intervention. Future Med Chem. 2:13391353.

McLean KJ, Carroll P, Lewis DG, Dunford AJ, Seward HE, Neeli R, Cheesman MR, Marsollier L, Douglas P, Smith WE, Rosenkrands I, Cole ST, Leys D, Parish T, Munro AW, Characterization of active site structure in CYP121. (2008). A cytochrome P450 essential for viability of Mycobacterium tuberculosis H37Rv. J Biol Chem 283:33406-33416.

McLean KJ, Dunford AJ, Neeli R, Driscoll MD, Munro AW (2007) Structure, function and drug targeting in Mycobacte- rium tuberculosis cytochrome P450 systems. Arch Biochem Biophys 464:228-240.

Mehra S, Kaushal D (2009) Functional Genomics Reveals Extended Roles of the Mycobacterium tuberculosis Stress Response Factor. J Bacteriol 191:3965-3980.

Mougous JD, Senaratne RH, Petzold CJ, Jain M, Lee DH, Schelle MW, Leavell MD, Cox JS, Leary JA, Riley LW, Bertozzi CR (2006) A sulfated metabolite produced by sft3 negatively regulates the virulence of Mycobacterium tuberculosis. Proc Natl Acad Sci USA 103:4258-4263.

Nikaido H, Vaara M (1985) Molecular basis of bacterial outer membrane permeability. Microbiol Rev 49:1-32.

Onwueme KC, Ferreras JA, Buglino J, Lima CD, Quadri LE (2004) Mycobacterial polyketide-associated proteins are acyltransferases: proof of principle with Mycobacterium tuberculosis PapA5. Proc Natl Acad Sci USA 101:4608-4613.

Ouellet H, Johnston JB, Ortiz de Montellano PR (2010) The Mycobacterium tuberculosis cytochrome P450 system. Arch Biochem Biophys 493:82-95.

Provvedi R, Boldrin F, Falciani F, Palù G, Manganelli R (2009) Global transcriptional response to vancomycin in Mycobacterium tuberculosis. Microbiology 155:1093-1102.

Ramakrishnan L, Federspiel NA, Falkow S (2000) Granulomaspecific expression of Mycobacterium virulence proteins from the glycine-rich PE-PGRS family. Science. 288:1436-1439.

Rodriguez GM, Smith I (2006) Identification of an ABC transporter required for iron acquisition and virulence in $\mathrm{Myco-}$ bacterium tuberculosis. J Bacteriol 188:424-430.

Rousseau C, Winter N, Pivert E, Bordat Y, Neyrolles O, Avé P, Huerre M, Gicquel B, Jackson M (2004) Production of phthiocerol dimycocerosates protects Mycobacterium tuberculosis from the cidal activity of reactive nitrogen intermediates produced by macrophages and modulates the early immune response to infection. Cell Microbiol 6:277-287.

Ryndak MB, Wang S, Smith I, Rodriguez GM (2010) The Mycobacterium tuberculosis High-Affinity Iron Importer, IrtA, Contains an FAD-Binding Domain. J Bacteriol 192:861869.

Sacks LE, Humphreys EM (1951) Antagonistic effect of serum on bacteriostatic action of lupulone. Proc Soc Exp Biol Med $76: 234-238$

Shasmal M, Sengupta J (2012) Structural diversity in bacterial ribosomes: mycobacterial 70S ribosome structure reveals novel features. PLoS One. 7:31742.

Siragusa GR, Haas GJ, Matthews PD, Smith RJ, Buhr RJ, Dale NM, Wise MG (2008) Antimicrobial activity of lupulone against Clostridium perfringens in the chicken intestinal tract jejunum and caecum. J Antimicrob Chemother 61:853-858

Slayden RA, Knudson DL, Belisle JT (2006) Identification of cell cycle regulators in Mycobacterium tuberculosis by inhibition of septum formation and global transcriptional analysis. Microbiology $152: 1789-1797$.

Stewart GR, Wernisch L, Stabler R, Mangan JA, Hinds J, Laing KG, Young DB, Butcher PD (2002) Dissection of the heatshock response in Mycobacterium tuberculosis using mutants and microarrays. Microbiology 148:3129-3138.

Strong M, Sawaya MR, Wang S, Phillips M, Cascio D, Eisenberg D (2006) Toward the structural genomics of complexes: Crystal structure of a PE/PPE protein complex from Myco- 
bacterium tuberculosis. Proc Natl Acad Sci USA 103:8060-8065.

Tagashira M, Watanabe M, Uemitsu N (1995) Antioxidative activity of hop bitter acids and their analogues. Biosci Biotechnol Biochem 59:740-742.

Teuber M, Schmalreck AF (1973) Membrane leakage in Bacillus subtilis 168 induced by the hop constituents lupulone, humulone, isohumulone and humulinic acid. Arch Mikrobiol 94:159-171.

Trivedi OA, Arora P, Sridharan V, Tickoo R, Mohanty D, Gokhale RS (2004) Enzymic activation and transfer of fatty acids as acyl-adenylates in mycobacteria. Nature 428:441445.

Tyagi JS, Saini DK (2004) Did the loss of two-component systems initiatepseudogene accumulation in Mycobacterium leprae? Microbiology 150:4-7.

Vordermeier HM, Hewinson RG, Wilkinson RJ, Wilkinson KA, Gideon HP, Young DB, Sampson SL (2012) Conserved immune recognition hierarchy of mycobacterial PE/PPE proteins during infection in natural hosts. PLoS One. 7, e40890. doi: 10.1371/journal.pone.0040890.

Youm J, Saier MHJr (2012) Comparative analyses of transport proteins encoded within the genomes of Mycobacterium tu- berculosis and Mycobacterium leprae. Biochim Biophys Acta. 1818:776-97.

Yu L, Guo N, Meng R, Liu B, Tang X, Jin J, Cui Y, Deng X (2010) Allicin-induced global gene expression profile of Saccharomyces cerevisiae. Appl Microbiol Biotechnol 88:219-229.

Yu L, Xiang H, Fan J, Wang D, Yang F, Guo N, Jin Q, Deng X (2008) Global transcriptional response of Staphylococcus aureus to rhein, a natural plant product. J Biotechnol 135:304-308.

Yu L, Zhang W, Wang L, Yang J, Liu T, Peng J, Leng W, Chen L, Li R, Jin Q (2007) Transcriptional profiles of the response to ketoconazole and amphotericin B in Trichophyton rubrum. Antimicrob Agents Chemother 51:144-153.

Zhao F, Nozawa H, Daikonnya A, Kondo K, Kitanaka S (2003) Inhibitors of nitric oxide production from hops (Humulus lupulus L.). Biol Pharm Bull 26:61-65.

\section{Supplementary Material}

Table S1: A list of genes with expression changes of at least 2.0 fold in M. tuberculosis H37Rv exposed to Lupulone.

All the content of the journal, except where otherwise noted, is licensed under a Creative Commons License CC BY-NC. 